\section{Ashhepkova N. Kulagin A.}

\title{
APPLICATION OF RECOMMENDATION BLOCKS FOR CONVERSION MANAGEMENT OF THE INTERNET STORE
}

Представлено результати експериментального дослідження системи керування конверсією інтернет-магазина. Розглянуто ефективність використання найбільш поширених рекомендаційних блоків: «Схожі товари», «Популярні товари», «Хіти продажів», «Супутні товари», «Новинки», «Акційні товари». Як оцінка ефективності модернізацї системи керування конверсією наведено відношення отриманого додаткового прибутку до витрат на вдосконалювання сайту (розміщення рекомендащійних блоків і створення внутрішнього взаємозв'язку між товарами).

Ключові слова: інтернет-магазин, супутні товари, комплектуючі товари, середній чек замовлення, система керування конверсією.

\section{Introduction}

Modern society can't be imagined without the use of an Internet network. Billions of users visit millions of websites every day, which can be divided into target accessories. Internet trading is one of the most common branches of the Internet business. Advantages of trading using the Internet site are obvious: the reduction of storage facilities, the lack of exhibition models of the goods, reducing the cost of rent and wages. All this, combined with software and hardware to implement the demand management system, allows to achieve even greater profits.

The relevance of this work is in the demand for scientifically based methods for obtaining the leading positions in the market with a constant increase in the number of online stores and increased competition.

\section{The object of research and its technological audit}

The management system is a systematized set of means of gathering information about a managed object and means of influencing its behavior intended to achieve certain goals. The object of the management system can be both technical objects and people. The management system object can consist of other objects that can have a permanent relationship structure. Technical management structure is a device or set of devices for manipulating the behavior of other devices or systems. The control object can be any dynamic system or its model. The state of the object is characterized by state variables, there are certain quantitative quantities that vary with time.

The object of research is a conversion management system for Internet commerce. The object of research consists of other objects - segment groups of users who have a diverse structure of relationships (for example, «children - parents», «men - women», «housewives - business ladies», etc.).

Variable states can be: purchasing power of the customer, prices in comparison with competitors, the number of competitors, the economic situation in the country, the type of goods presented in the store, etc.

Now there is no scientifically sound methodology for controllable impact on the demand of the selected segment of the users of the online store and assessing the growth in conversion as a result of the site's modernization

\section{The aim and objectives of research}

The aim of research is development of an algorithm for the modernization of the conversion management system, its implementation and analysis of sales growth.

To achieve the aim in the course of the study the following tasks are solved:

1. To develop an algorithm for upgrading the online store conversion management system.

2. To highlight the basic parameters of the online store conversion management system:

3. To investigate the effect of changing key parameters on the increase in conversion.

4. To estimate their weight coefficient as a component of the optimal result.

5. To evaluate the obtained results, based on the ratio of the resulting additional profit to the cost of creating a conversion management system.

\section{Research of existing solutions of the problem}

The implementation of Web technologies into Business Intelligence is not a new idea: for many years companies have used the HTML (hypertext markup language) as an inexpensive and relatively simple way of distributing static information in the form of a permanent reporting format. However, there are difficulties associated with the peculiarities of the HTTP file transfer protocol, which does not provide for the storage of previous states and does not support permanent connections, which is necessary for unregulated analysis.

To solve this problem, manufacturers of BI-tools turned to Java and ActiveX technologies, allows to significantly 
expand the HTML functions. This, on the one hand, has made it possible to provide more sophisticated interactive analysis capabilities. But on the other hand, due to a significant increase in the amount of information loaded by the Web browser, the issue of network bandwidth and connection speed was sharply raised. In addition, these technologies are not supported by all platforms and browsers.

Now there are more functional and reliable approaches to implementing BI on the Web. It is proposed to use software components based on DCOM (Distributed Common Object Model) technologies and Microsoft .NET, as well as CORBA Common Object Request Broker Architecture and EJB (Enterprise Java Beans) technology implemented on the J2EE platform (Java 2 Enterprise Edition). These components are used to create middle-tier Web services between the HTTP server and the database, control connection processing with the application's database and logic, eliminating the need to download and process the code on the client.

It is also important to note that the middle-tier software component is not just a link, but part of multi-tier application architecture. Using such architecture reduces the time and material costs required to distribute applications and load balancing between new servers as the number of users increases. For end-users, this technology provides faster, more consistent and reliable access to the necessary information.

The widespread use of Internet technology in shopping increases the number of visitors to online stores. The desire to increase revenue from sales in the network can be represented as maximizing the number of visitors and increasing efficiency that is, increasing the level of sales (conversion).

Providing recommendations on the accompanying and completing products on the card of the ordered goods, the online store increases the usability of the site helps the user make the next purchase, offers an alternative and simplifies the choice $[1,2]$.

Using the book [3], the author of numerous works on web technologies, it is possible to create dynamic sites characterized by a high level of interaction with users. R. Nixon offers a combination of PHP and MySQL, which facilitate the creation of modern websites, and add to these technologies the javascript capabilities, which allows to create high-tech applications.

In the book [4], which is considered one of the most influential experts in the field of usability and site conversion, simple and effective solutions for optimizing Internet projects and moving them to an entirely new level of impact is offered. Author proposes available methods (including the basics of usability and search engine optimization), which will help to significantly increase the site's traffic. In addition, professional techniques are pre- sented that will help keep visitors' attention and turn them into customers or regular users. The publication contains hundreds of tips and tips, as well as several detailed cases for optimizing individual web pages.

Attention of the authors [5-8] is aimed at improving, increasing the attractiveness, «brightness» of web pages.

At present, there are practically no reliable methods for assessing the effectiveness of conversion management. The question arises: «How are the costs of site modernization and the expected or real increase in sales (conversion)?» In addition, the same control impact can have different «reviews» for individual segment groups of users.

\section{Methods of research}

To study the online store conversion management system, it is possible to change the graphic or content parameters. To assess the effectiveness of upgrading the conversion management system, it is possible to use: the total number of visitors, the total amount of sales for a certain period of time, a gain in profits, etc.

The authors investigated the meaningful improvement of the online store's website, but the placement of the advisory blocks and the creation of an internal relationship between the goods.

To assess the effectiveness of the modernization of the conversion management system, the ratio of the received additional profit to the costs for improving the site is given.

\section{Research results}

1. The algorithm of modernization (development) of the conversion management system (Table 1) consists of the following steps:

- Diagnosis of the existing conversion management system.

- Design of a new demand management system.

- Verification and preliminary approval of the project.

- Detailed study of the new project.

- Implementation of a new conversion management system.

Table 1

Algorithm for the modernization (development) of the conversion management system

\begin{tabular}{|c|l|l|l|}
\hline No. & \multicolumn{1}{|c|}{ Step } & \multicolumn{1}{|c|}{ List of main actions } & \multicolumn{1}{c|}{ Results } \\
\hline 1 & $\begin{array}{l}\text { Diagnosis of the existing con- } \\
\text { version management system }\end{array}$ & $\begin{array}{l}\text { Carrying out of diagnostics of organizational struc- } \\
\text { ture and business processes. } \\
\text { Identify the problems that prevent conversion. } \\
\text { Identify recommendations for problem solving }\end{array}$ & $\begin{array}{l}\text { Report on diagnostics of the } \\
\text { conversion management sys- } \\
\text { tem }\end{array}$ \\
\hline 2 & $\begin{array}{l}\text { Design of a new demand ma- } \\
\text { nagement system }\end{array}$ & $\begin{array}{l}\text { Development of technical solutions for the imple- } \\
\text { mentation of recommendations. } \\
\text { Formation of a new organizational and functional } \\
\text { model of the online store }\end{array}$ & $\begin{array}{l}\text { Organizational and functional } \\
\text { model of the online store }\end{array}$ \\
\hline 3 & $\begin{array}{l}\text { Verification and preliminary } \\
\text { approval of the project } \\
\text { model of the online store for compliance with the } \\
\text { claimed requirements. } \\
\text { Justification of the choice of an alternative version } \\
\text { of the conversion management system. } \\
\text { Coordination with the customer }\end{array}$ & $\begin{array}{l}\text { Approved project management } \\
\text { system for converting an on- } \\
\text { line store }\end{array}$ \\
\hline 4 & $\begin{array}{l}\text { Detailed study of the new } \\
\text { project }\end{array}$ & $\begin{array}{l}\text { Development of a detailed project implementa- } \\
\text { tion plan. } \\
\text { Development of a package of organizational and } \\
\text { regulatory documents }\end{array}$ & $\begin{array}{l}\text { Project implementation plan. } \\
\text { A package of organizational } \\
\text { and regulatory documents (re- } \\
\text { gulations, job descriptions) }\end{array}$ \\
\hline 5 & $\begin{array}{l}\text { Implementation of a new con- } \\
\text { version management system }\end{array}$ & $\begin{array}{l}\text { Implementation of activities in accordance with the } \\
\text { plan for implementing a new management system }\end{array}$ & $\begin{array}{l}\text { Organizational and regulatory } \\
\text { documents }\end{array}$ \\
\hline
\end{tabular}




\section{Investigation of the effect of changing the basic} parameters of the conversion management system on sales growth. Depending on the specific nomenclature of goods, the demand management systems can differ very much in their functions, architecture and implementation method. However, it is possible to distinguish at least two properties that are common to all demand management systems in the online store. First, any demand management system is designed to collect, store and process information. Therefore, they are based on the storage and access to data environment. The environment must ensure reliable storage and efficient access to information. Secondly, demand management systems are oriented towards the end user, in our case the client of the online store. The demand management system should take into account the level of education of the user, so the online store should have a simple, convenient, easy to learn and bright interface. The online store's demand management system should provide the end user with all the functions, tips, necessary for its work, but at the same time prevent from performing any unnecessary actions (reading horoscopes, weather forecasting, news, etc.). Most often, the interface of the online store - a graphical menu, which is filled with «hot» buttons, tips, etc.

After all, simply creating a «buy» button is not enough. It is necessary to develop an interface in accordance with the expectations of the user, as well as to develop and implement a conversion management system.

To create such systems, analysts of business processes, programmers, testers, system integrators, engineers for the implementation and adaptation of software products are involved.

6.1. Experimental researches. For the purity of the experiment, a conversion was considered for the same website for equal periods of time; Users is segmented into three subgroups.

Almost all products have accessories or alternative and novelties. It is possible to inform the user about this by means of recommendation blocks.

The recommended blocks on the product card help to:

- increase the number of pages on the site, thereby increasing the number of products demonstrated to the visitor and ultimately increasing sales [3];

- increase the average order check, as the probability that the visitor will not leave the site with one purchase will increase, and using useful recommendations and tips will supplement his basket with additional goods;

- tie the goods together, that is, improve navigation on the site and simplify the user search [4];

- increase traffic on low-frequency requests due to a competent distribution of the static weight of the site pages through internal interconnection.

The efficiency of using the most popular recommended blocks is considered: «Similar goods», «Popular goods», «Hits of sales», «Related products», «New products», «Promotional products». Table 2 shows the ratio of the resulting additional profit to the costs of improving the site (placement of advisory blocks and the creation of an internal relationship between goods).

To increase the conversion of the online store, it is advisable to add the recommended blocks: «Similar goods», «Related products», «New products», «Promotional products».
Table 2

Description of page layout

\begin{tabular}{|c|c|}
\hline Name of the recommendation blocks & Relative extra profit \\
\hline «Similar goods» & 1.3 \\
\hline «Popular goods» & 1 \\
\hline «Hits of sales» & 0.9 \\
\hline «Helated products» & 1.6 \\
\hline «New products» & 1.3 \\
\hline «Promotional products» & 1.6 \\
\hline
\end{tabular}

\section{SWOT analysis of research results}

Strengths. Positive features of the object of research is the sensuality of the conversion management system within a particular segment of the user group (changes in content and graphical parameters determine the dynamics of online trade conversions). In addition, the introduction of communication products between themselves and the demonstration of related and promotional products has a synergistic effect, that is, increases the total sales.

Weaknesses. Negative features of the object of research are the multiple connection of the conversion management system. Making a purchase in an online store can be either purposeful or spontaneous. Users can view a variety of products, but do not make the final choice as a result of subjective reasons (fatigue, bad mood, etc.). It's very difficult to evaluate the user's psychological readiness for buying.

Opportunities. Further development of conversion management systems is advisable to use mathematical methods of game theory, with a miscalculation of the most optimistic and pessimistic strategy. In this case, the real user will choose a strategy that belongs to some allowable gap.

Threats. The development of effective management systems for the conversion and supply of imported high-quality goods to users can negatively affect the domestic producer. For small and medium-sized businesses, the development of a quality website, its updating and modernization, can lead to additional costs.

\section{Conclusions}

1. An algorithm for the modernization of the online store conversion management system is developed. For each step of the algorithm, a list of the main actions and the expected result is determined.

2. Graphic and content parameters of the online store conversion management system are highlighted. The substantial modernization of the site consisted in the consistent application of the most common recommended blocks: «Similar goods», «Popular goods», «Hits of sales», «Related products», «New products», «Promotional products».

3. The influence of the meaningful improvement of the site of the online store, and the placement of the advisory blocks themselves and the creation of an internal relationship between the goods, an increase in the conversion, are studied experimentally.

4. Evaluation of the efficiency of the modernization of the conversion management system calculated as the ratio of the additional profit received to the costs of improving the site. 
5. For the various management actions (site changes), an evaluation of the efficiency is calculated. The obtained partial results can be considered weight coefficients, or as components of the overall result.

The availability of the advisory blocks « Related products» and «Promotional products» increases the relative additional profit by 1.6 times (by $60 \%$ ). The application of the similar blocks «Similar goods» and «New products» increases the relative additional profit by 1.3 times (by $30 \%$ ). The recommendation block «Hits of sales» reduces the average order check by $10 \%$, it is proposed to be used for a segment of buyers prone to spontaneous purchases.

The recommendations on the use of modern methods of increasing the level of sales are theoretically substantiated and confirmed by the obtained experimental data. Experimental studies have shown the possibility of mathematical modeling of conversion management system by matrix games $[9,10]$.

\section{References}

1. Scott, B. Designing Web Interfaces: Principles and Patterns for Rich Interactions [Text] / B. Scott, T. Neil. - O'Reilly Media, 2009. - $334 \mathrm{p}$

2. Kolisnichenko, D. N. PHP i MySQL. Razrabotka Web-prilozhenii [Text] / D. N. Kolisnichenko. - St. Petersburg: BHVPeterburg, 2013. - 543 p.

3. Nixon, R. Learning PHP, MySQL \& JavaScript: With jQuery, CSS \& HTML5 (Learning Php, Mysql, Javascript, Css \& Html5) [Text] / R. Nixon. - Ed. 4. - O'Reilly Media, 2014. - 812 p.

4. Hunt, B. Convert!: Designing Web Sites to Increase Traffic and Conversion [Text] / B. Hunt. - Wiley, 2011. - 312 p.

5. Borisenko, A. A. Web-dizain. Prosto kak dvazhdy dva [Text] A. A. Borisenko. - Moscow: Eksmo, 2008. - 320 p.

6. Syryh, Yu. A. Sovremennyi veb-dizain. Risuem sait, kotoryi prodaet [Text] / Yu. A. Syryh. - Moscow: OOO »Williams», 2008. - 304 p.
7. Rusakov, M. Sozdanie saita ot nachala i do kontsa [Text] / M. Rusakov. - Internet-Izdanie, 2014. - 172 p.

8. Tsifrovoi dizain: osnovy veb-proektirovaniia s pomoshch'iu instrumentov Adobe [Text]. - Internet-Izdanie, Rid Grupp 2012. - 1357 p.

9. Vorobiov, N. N. Teoriia igr dlia ekonomistov-kibernetikov [Text]/ N. N. Vorobiov. - Moscow: Nauka, 1985. - 272 p.

10. Owen, G. Game Theory [Text] / G. Owen. - Ed. 3. - Emerald Group Publishing Limited, 1995. - 460 p.

\section{ПРИМЕНЕНИЕ РЕКОМЕНДАЦИОННЫХ БЛОКОВ ДЛЯ УПРАВЛЕНИЯ} КОНВЕРСИЕЙ ИНТЕРНЕТ-МАГАЗИНА

Представлены результаты экспериментального исследования системы управления конверсией интернет-магазина. Рассмотрена эффективность использования наиболее распространенных рекомендационных блоков: «Похожие товары», «Популярные товары», «Хиты продаж», «Сопутствующие товары», «Новинки», «Акционные товары». В качестве оценки эффективности модернизации системы управления конверсией представлено отношение полученной дополнительной прибыли к расходам на усовершенствование сайта (размещение рекомендательных блоков и создание внутренней взаимосвязи между товарами).

ключевые слова: интернет-магазин, сопутствующие товары, комплектующие товары, средний чек заказа, система управления конверсией.

Ashhepkova Natalja, PhD, Associate Professor, Department of Mechatronics, Oles Honchar Dnipropetrovsk National University, Dnipro, Ukraine, e-mail: ashhepkova_natalja@rambler.ru, ORCID: http://orcid.org/0000-0002-1870-1062

Kulagin Anton, Postgraduate Student, Department of Mechatronics, Oles Honchar Dnipropetrovsk National University, Dnipro, Ukraine, ORCID: http://orcid.org/0000-0001-9257-2708 